\title{
Sprawozdanie z konferencji naukowej pt. Europa Christiana. Konwersji władcy, sakralizacji władzy, chrystianizacji poddanych. Colloquia Mediaevalia Gnesnensia IV, Gniezno 19-2o X 2016 r. ${ }^{1}$
}

Od 19 do 20 X 2016 r. w Instytucie Kultury Europejskiej UAM w Gnieźnie miało miejsce czwarte spotkanie z cyklu „Colloquia Mediaevalia Gnesnensia”. Tegoroczna edycja poświęcona była zagadnieniom konwersji władcy, sakralizacji władzy i chrystianizacji poddanych, a konferencja została wspólnie zorganizowana przez Miasto Gniezno, Instytut Historii UAM w Poznaniu oraz Instytut Kultury Europejskiej UAM w Gnieźnie.

Obrady podzielone zostały na dwie części. W trakcie pierwszej z nich uczestnicy skupili uwagę na zagadnieniu władców chrystianizatorów. Natomiast druga część została poświęcona problematyce ideologii władzy oraz kościołowi i jego strukturom.

Oficjalne otwarcie konferencji nastąpiło 19 października w godzinach porannych. Zaproszonych gości powitali prof. dr hab. Leszek Wetesko oraz Dyrektor Instytutu Kultury Europejskiej w Gnieźnie prof. dr hab. Leszek Mrozewicz. Słowo wstępne wygłosił także dziekan Wydziału Historycznego UAM prof. dr hab. Kazimierz Ilski oraz dyrektor Instytutu Historii UAM prof. dr hab. Józef Dobosz.

W pierwszej części spotkania przedstawione zostały trzy referaty. Pierwszy z nich, autorstwa prof. dra hab. Kazimierza Ilskiego (UAM), dotyczył wykorzy-

1 Praca naukowa finansowana w ramach programu Ministra Nauki i Szkolnictwa Wyższego pod nazwą „Narodowy Program Rozwoju Humanistyki” w latach 2014-2019 (projekt nr 0046/NPRH3/H11/82/2014). 
stania chrześcijaństwa, jako narzędzia promowania władcy i propagandy politycznej u schyłku antyku (Promotorzy chrześcijaństwa u schyłku antyku). Następnie dr hab. Anna Kotłowska (UAM) przybliżyła słuchaczom wątki zoroastrianskie pojawiające się w „Historii Powszechnej” Teofilakta Simokatty (Kwestie religijne w „Historii Powszechnej” Teofilakta Simokatty). Ostatnie, przed przerwą wystąpienie poświęcone było rozważaniom na temat idei posłannictwa misyjnego we wczesnym średniowieczu ( $Z$ Rzymu do pogan - działalność misyjna w czasach merowińskich). Referat na ten temat wygłosił mgr Maksymilian Sas (Uniwersytet Warszawski).

Popołudniowy panel rozpoczął mgr Paweł Figurski (Uniwersytet Warszawski), który przedstawił sposoby sakralizowania i chrystianizowania wczesnośredniowiecznych panujących w tekstach modlitw ( $O$ chrystianizacji oraz sakralizacji karolińsko-ottońskiej wtadzy na podstawie liturgicznych modlitw za rzadzacych). Kolejny referat dotyczył chrześcijańskich władców z dynastii Mojmirowiców oraz wpływu kościoła merowińskiego i frankijskiego na państwo wielkomorawskie (Wielkomorawscy Mojmirowice wobec chrześcijanstwa). Autorem referatu był prof. dr hab. Krzysztof Polek (Uniwersytet Pedagogiczny w Krakowie). Następnie prof. dr hab. Edward Skibiński zaprezentował podstawy źródłowe dotyczące chrztu Mieszka I i początków chrześcijaństwa w państwie pierwszych Piastów (Polska Piastów czyli Mesco dux baptizatur). Jako ostatni, w tej części obrad, głos zabrał prof. dr hab. Leszek Słupecki (Uniwersytet Rzeszowski). Badacz ten przybliżył słuchaczom problematykę związaną z misjami chrześcijańskimi na obszar Skandynawii oraz koronacjami władców z tego kręgu (Chrystianizacja ludów Pótnocy).

Po przerwie PhDr. Ivo Štefan, PhD. (Uniwersytet Karola w Pradze) podjął się rozważań dotyczących związku obrządku pogrzebowego z chrystianizacją, konfrontując źródła archeologiczne z pisanymi (Za časủ jeho otce, který byl ještě pohan... Kremace, inhumace a christianizace). Kolejny prelegent, mgr Jacek Wrzesiński (Rezerwat Archeologiczny Gród w Grzybowie Oddział Muzeum Pierwszych Piastów na Lednicy), pozostając przy tematyce sepulkralnej, przedstawił najstarsze pochówki szkieletowe na ziemiach Piastów (Konwersja piastowskich poddanych - gdzie sa najstarsze groby szkieletowe?). Pierwszy dzień konferencji zakończył referat poświęcony kompleksowi architektonicznemu na Wyszehradzie oraz jego związkom z panowaniem Wratysława II. Wygłosił go mgr Ladislav Varadzin, PhD. (Czeska Akademia Nauk, Praga).

Drugi dzień konferencji rozpoczęło wystąpienie prof. dra hab. Stanisława Rosika (Uniwersytet Wrocławski). Dotyczyło ono instytucjonalnego wymiaru chry- 
stianizacji oraz konwersji ludów zamieszkujących Połabie (Stowianie Połabscy na drodze ku chrystianizacji). Kolejny referat wygłosiła dr Magdalena Biniaś-Szkopek (UAM), która podjęła tematykę wypraw misyjnych na tereny plemion pruskich (Piastowskie próby chrystianizacji Prusów na przełomie XII/XIII wieku). Następnie problematykę chrystianizacji, ewangelizacji i sakralizacji władzy w kręgu francuskim (Kapetyngowie jako królowie-chrystianizatorzy), przedstawił dr hab. Jerzy Pysiak (Uniwersytet Warszawski).

Po krótkiej przerwie głos zabrał prof. dr hab. Zbigniew Dalewski (Instytut Historii im. Tadeusza Manteuffla PAN). Jego referat skoncentrowany był na kwestiach dotyczących mechanizmów sakralizacji władcy w kręgu piastowskim (Sacrum a ideologia wtadzy w średniowieczu). Następnie prof. dr hab. Leszek Wetesko (UAM), który na przykładzie architektury średniowiecznej, przedstawił zjawisko przenikania się ideologii władzy i sacrum chrześcijańskiego (Chrześcijańskie sacrum w przestrzeni władzy wcześniejszego średniowiecza). Jako ostatni w trakcie tegorocznych obrad wystąpił dr Marcin Danielewski (UAM). Badacz ten skoncentrował uwagę słuchaczy na grodach wczesnopiastowskich (Grodycentra kościelne wtadztwa Piastów w X-XI wieku?).

Podsumowania oraz oficjalnego zamknięcia konferencji dokonał prof. dr hab. Józef Dobosz. W trakcie trwania naukowej sesji uczestnicy mieli okazję wysłuchać łącznie 16 wystąpień badaczy z Polski oraz z zagranicy. Warto zwrócić uwagę, że znaczny odsetek prelegentów stanowili także młodzi naukowcy, co świadczyć może o tym, że przedsięwzięcia, takie jak gnieźnieńska konferencja, przyczyniają się do rozwoju młodej kadry naukowej. Cieszy również to, że w organizowanie tego typu wydarzeń angażują się środowiska pozanaukowe, takie jak Miasto Gniezno.

mgr Ziemowit Kraska,

Instytut Historii, Wydział Historyczny, Uniwersytet im. Adama Mickiewicza, ul. Umultowska 89d, 61-614 Poznań, ziemowit.kraska@o2.pl 